\title{
CHRONOLOGY
}

This chronology builds upon that compiled by Reginald Gibbons, published in William Goyen: A Study of the Short Fiction (Boston: Twayne Publishers, I99I). It in turn was based, in part, on the chronology in my William Goyen (Boston: Twayne Publishers, 1979). The reader will notice numerous discrepancies from both, however. In accumulating and studying Goyen's letters-almost all of which were dated-I became aware that certain dates and events had been misrepresented or misremembered in earlier conversations with the author. For example, Goyen's translation of Albert Cossery's The Lazy Ones (which was published without a copyright date) had been dated by me as 1949 and by Gibbons as 1950. It is now apparent that the book was published in $195^{2}$. Gibbons had Goyen living "off and on for a year" in London in 1949, when actually the writer did not arrive there until the autumn of that year. The film version of "The White Rooster" premiered in 1953, not I 955 or 1957 as previously cited. Goyen wrote his lyrics for the film The Left-Handed Gun in 1957, not 1955. And both earlier chronologies had Goyen traveling to Germany in 1961 and not returning until 1963 . His correspondence reveals that he was there a much briefer time. In conversation, Goyen liked to mythologize his German experience; it was perhaps important to him to feel so well accepted in that country, since he felt so ill-treated in this one.

I894 Birth of father, Charles Provine Goyen, in Crystal Springs, Mississippi.

I896 Birth of mother, Mary Inez (Emma) Trow, in Trinity, Texas. I9I5 (Charles) William Goyen born April 24 in Trinity, Texas. 1923 Father moves family briefly to Shreveport, Louisiana, then to 6I4 Merrill Street, Houston, where Goyen will grow up. 
1928-1932 Attends Sam Houston High School.

1932-1937 Attends Rice Institute, works part-time at Houston Public Library.

I936 Meets Margo Jones in the fall, joins the Houston Players, performs in dramas under her direction.

I937 Receives B.A. in literature from Rice, having taken prizes in both playwriting and short-story writing.

1937-1939 Pursues graduate studies at Rice Institute.

I939 Receives M.A. in comparative literature from Rice. Enrolls in $\mathrm{Ph} . \mathrm{D}$. program at University of Iowa, drops out after three months. Returns to Houston and teaches at University of Houston. Receives draft notice, enlists in the Navy.

I940 Serves in Houston in a Navy recruitment office. Attends Midshipmen's School at Columbia University in New York City.

I94I-1945 Serves as officer on the aircraft carrier Casablanca in the South Pacific. Begins writing first novel. Is hospitalized in I945.

I945 Receives discharge from service. Leaves for California by car with Walter Berns, friend from the Navy. Stops at Taos, New Mexico, in March and meets Frieda Lawrence. Stays in Taos, builds house on land in El Prado given him by Frieda Lawrence.

I946 Devotes full time to writing. First acceptance of fiction for publication, "The Evil," which appeared in The Illiterati 5 (1948): 3-4.

I947 Acceptances of "The White Rooster" and "A Parable of Perez." Meets James Laughlin. Travels to California with Berns. Meets Katherine Anne Porter in August.

I948 Works part-time as script reader in Dallas for Margo Jones. "Four American Portraits as Elegy" published in Accent. Meets Stephen Spender. Moves to Napa, California, in August, intending to teach at Reed College. Job falls through. Meets Eudora Welty in the autumn. Receives Southwest Review literary fellowship. Returns to Taos.

I949 Lives in London in the autumn, visits Paris. Completes first novel, The House of Breath. Is hospitalized at end of year for knee injury.

I950-195 I Leaves British hospital in February, returns to New York. Lives in New York, Chicago, and Houston while writing stories for Ghost and Flesh. Publication of The House of Breath 
on August 9, I950. Receives MacMurray Prize for best first novel by a Texan. Fellow at Yaddo. Beginning of affair with Katherine Anne Porter.

1952 Ghost and Flesh published. Wins a Guggenheim Fellowship. End of affair with Porter. Translation of Les Fainéants (The Lazy Ones) published. Meets the painter Joseph Glasco.

I953 Finishes Half a Look of Cain. Film version of "The White Rooster" premieres in Princeton. Publishes "The People of Joseph Glasco," text for an exhibition catalog, Catherine Viviano Gallery, Manhattan.

I954 Stage adaptation of The House of Breath produced offBroadway. Wins second Guggenheim Fellowship, lives in Rome and Naples.

1955 In a Farther Country, second published novel. Lives in New York. Play, The Diamond Rattler, produced in Boston. Whisper to $M e$, play adaptation of his story "The Letter in the Cedarchest," adapted by Greer Johnson, produced by Margo Jones in Dallas and New York. Begins five-year teaching stint at the New School for Social Research. Death of Margo Jones.

I956 Death of Frieda Lawrence.

I957 The House of Breath (play) produced in Manhattan at Circle in the Square. Moves to Bucks County, Pennsylvania. Travels to Hollywood to write lyrics for the film The LeftHanded Gun.

I958 Release of The Left-Handed Gun. Sells his house in Taos. 1960 The Faces of Blood Kindred, second story collection, published. The Diamond Rattler produced in Boston. Quits teaching job at the New School.

196I Travels in Germany as guest of State Department. Two television plays produced, $A$ Possibility of Oil on CBS TV and The Mind on ABC TV.

I962 Begins teaching position at university in Kiel, West Germany. Suddenly returns to United States in the spring.

1963 Receives Ford Foundation Grant for Theatre Writing. Fourth play, Christy, produced in New York with actress Doris Roberts. Marries Roberts on November 1o. The Fair Sister, third novel, published.

1964-1965 Teaches at Columbia University.

1965 Begins book of memoirs, Six Women.

I966 Publishes two critical commentaries, My Antonia and Ralph 
Ellison's Invisible Man. Assumes duties as Senior Trade Editor for McGraw-Hill publishers.

I968 Death of father on July i I.

I969 Playwright in residence, Trinity Square Repertory Company, Providence, Rhode Island. The House of Breath, Black/White produced.

I970 Visiting professor in the writing program, Brown University.

I97 I On staff of Southwest Writers' Conference, Houston, in July. Begins $A$ Book of Jesus. Leaves McGraw-Hill on October 29 to write full-time.

1972 Residency at Brown University.

I973 A Book of Fesus published. Again at Southwest Writers' Conference and Brown University.

1974 Fourth novel (Come, the Restorer) and Selected Writings of William Goyen published. Musical Aimee! (based on the life of Aimee Semple McPherson), with book and lyrics by Goyen, produced in Providence. Visits Paris and Madrid in September with wife and stepson. Teaches at Brown.

I975 The Collected Stories and Twenty-fifth Anniversary Edition of The House of Breath published. Gives address at Trinity University in San Antonio. Moves to Los Angeles from Manhattan in June.

I976 Nine Poems published in limited edition of 226 copies. Undergoes operation for detached retina. Writer in residence at Princeton University. Paris Review interview published.

1977 Receives Distinguished Alumni Award from Rice University. Returns to Princeton to teach.

I978 "William Goyen: A Bibliographic Chronicle," by Clyde Grimm, published. Terminates teaching at Princeton. Divides time between New York and Los Angeles. Undergoes operation for dupetrends. Delivers lecture at Houston Public Library, sponsored by the National Endowment for the Humanities.

I979 Artbur Bond published in limited edition of 230 copies. Special William Goyen Issue of Delta. William Goyen, by Robert Phillips, published. Is diagnosed as having lymphoma.

1980 Wonderful Plant published in limited edition of r6o copies. Has operation on left hand. Death of Katherine Anne Porter. 
I98I Precious Door published in limited edition of I I 5 copies. Teaches in spring semester at University of Houston.

I982 Is hospitalized in Los Angeles and released in remission. TriQuarterly interview published.

I983 Lectures in April at New York University on "Recovering." New Work and Work in Progress published in limited edition of 200 copies. Is hospitalized again in Los Angeles in summer. Dies on August 29. Arcadio, fourth novel, published in October.

I985 Had I a Hundred Moutbs: New and Selected Stories 1947-1983 published.

I986 William Goyen: A Descriptive Bibliography, $1938-1985$, by Stuart Wright, published by Meckler Publishing. "A propos de 'Suite Funèbre I' de Francis Mockel” published in exhibition catalog, Francis Mockel, Gravures, Centre de Développement Culturel de Boulogne-Sur-Mer.

1991 William Goyen: A Study of the Short Fiction, by Reginald Gibbons, published. William Goyen. Cabier coordonné par Patrice Repusseau, with a preface by Claude Mettra, published by Le Castor astral in France. "Marvello" chapter of Half a Look of Cain published in spring issue of Southern Review.

I992 William Goyen Issue of Mid-American Review published, including excerpts from The Diamond Rattler and three essays by Goyen.

I994 Half a Look of Cain published and Arcadio reissued.

I995 William Goyen: Selected Letters from a Writer's Life published. 
THIS PAGE INTENTIONALLY LEFT BLANK 


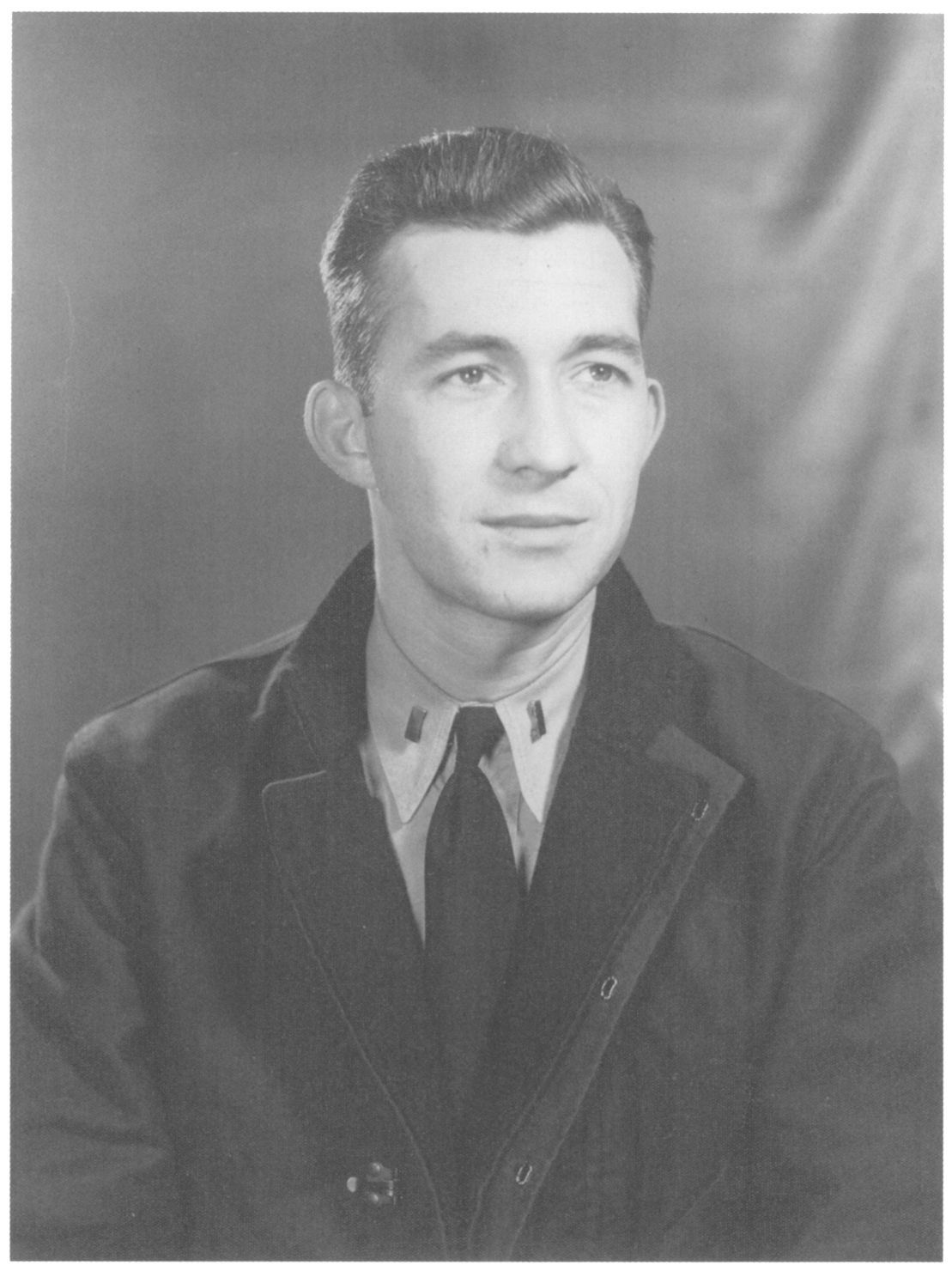

Goyen as a miserable, unshaven ensign, early ig4os. Courtesy of Walter Berns. 
Goyen and Walter Berns in Taos, late I940s. Courtesy of Walter Berns.

Goyen's adobe bouse in Taos.
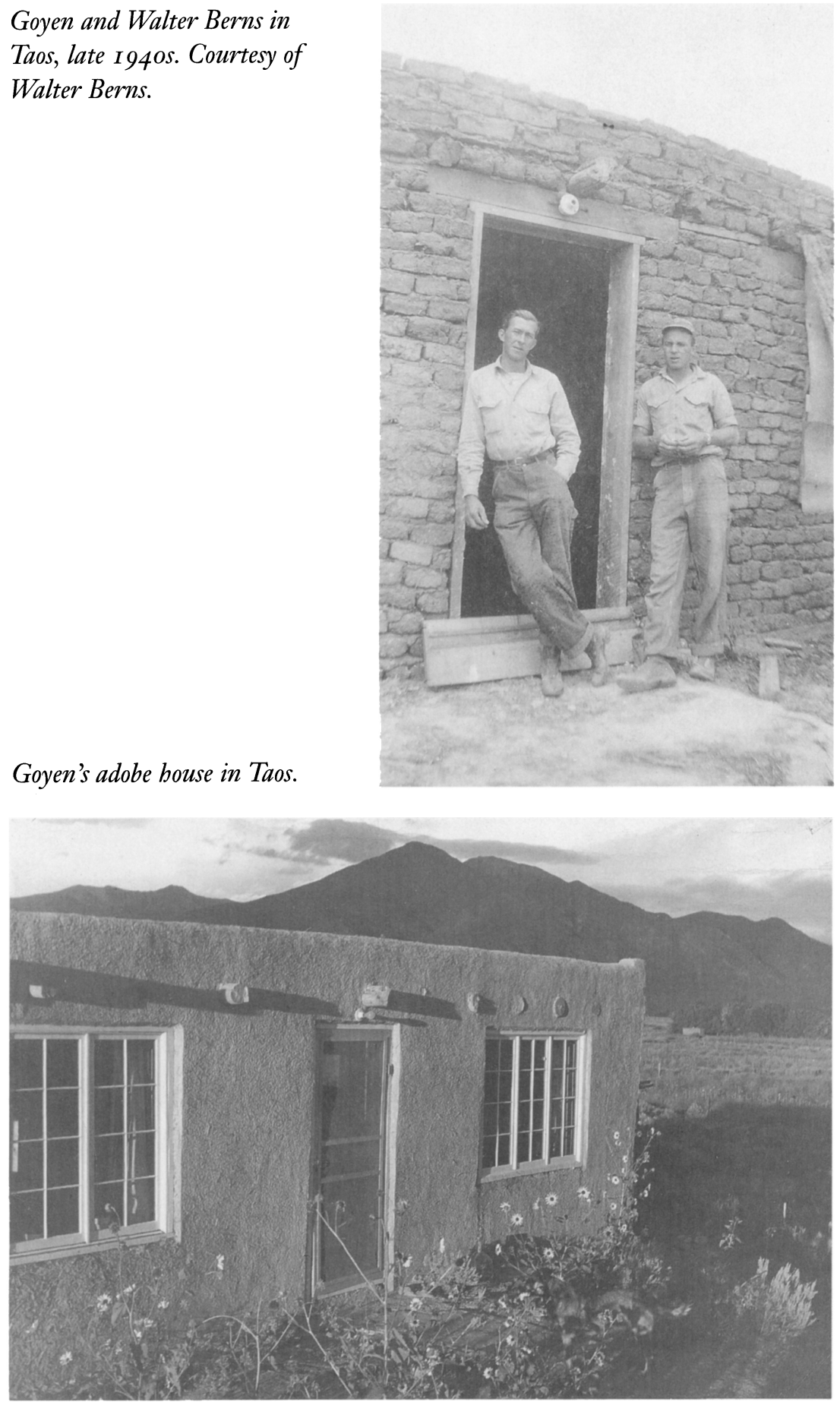


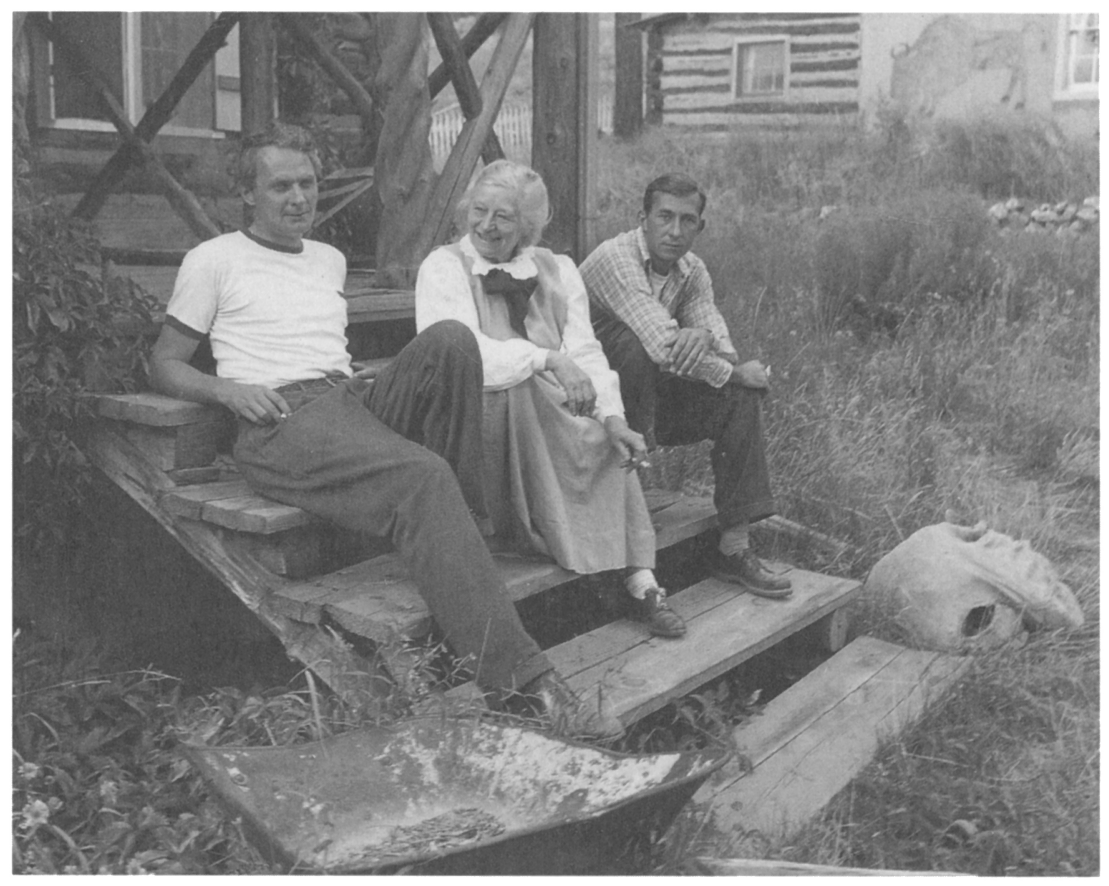

Stephen Spender, Frieda Lawrence, and Goyen at the Lawrence Ranch.

Dorotby Brett.

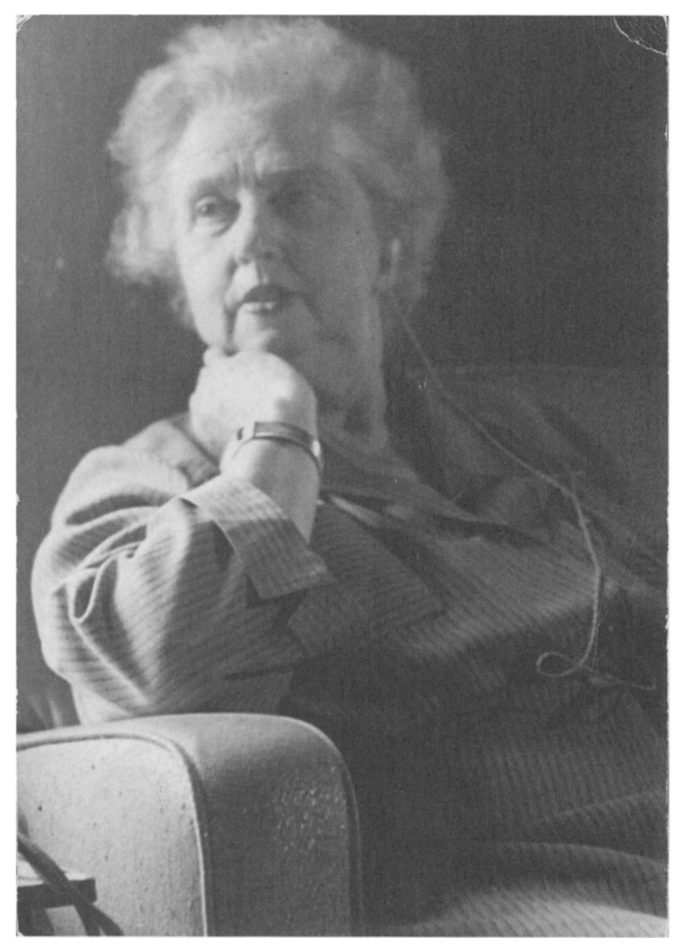




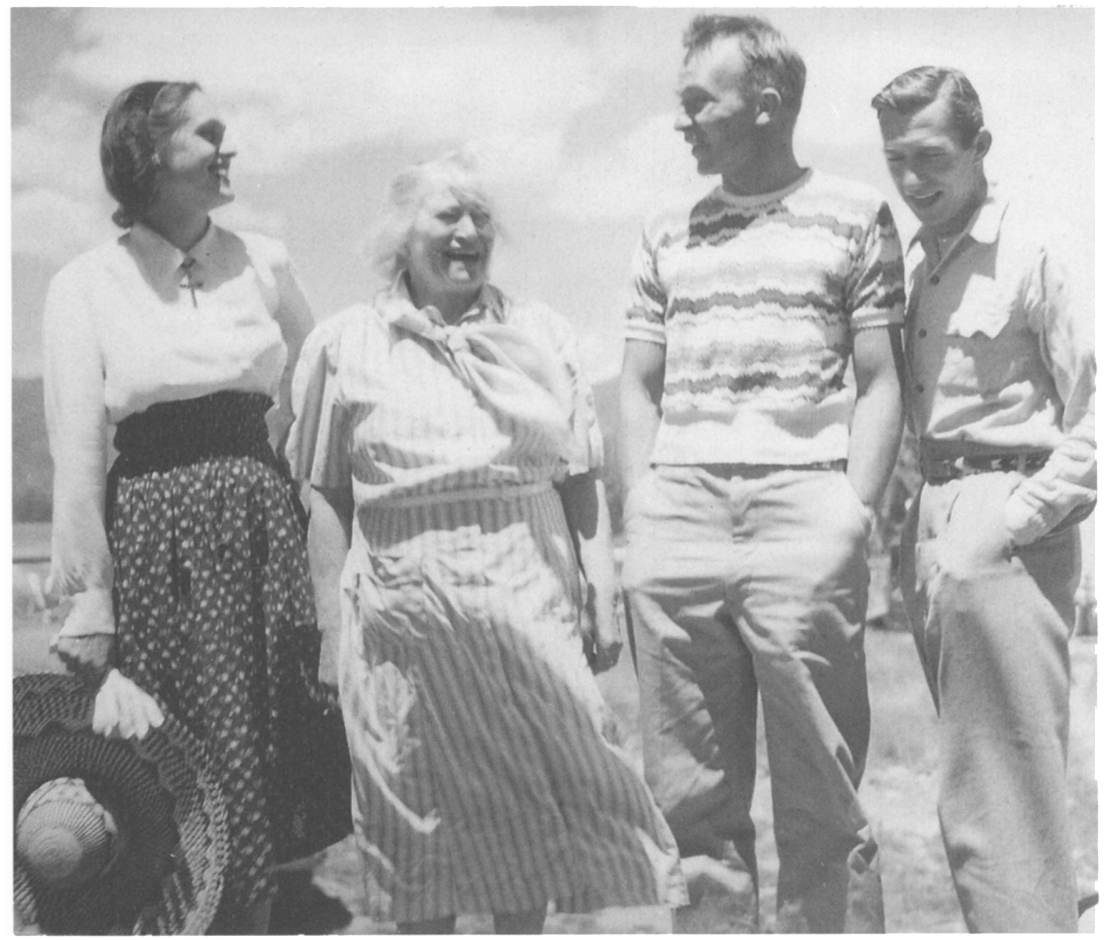

\section{Dorotby Robinson,}

Frieda Lawrence,

Walter Berns, and

Goyen in Taos.

Dorotby Robinson and

Goyen, 1949. Courtesy of Walter Berns.

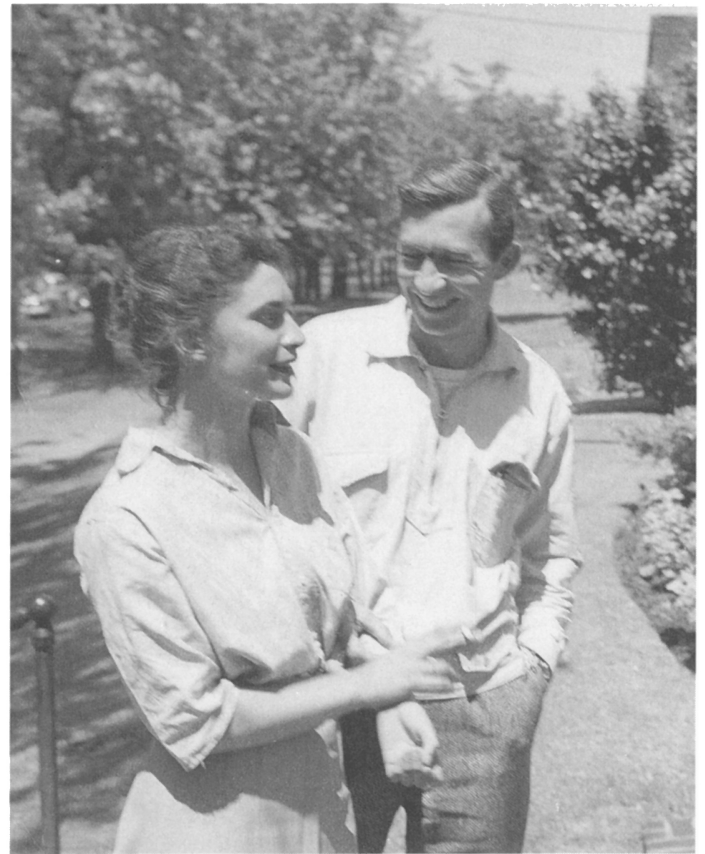


Margo fones, "The Texas Tornado."

Courtesy of the fones Family Archives,

Richard and Bea fones and Charles Fones, Houston, Texas.

The jacket photograph, later cropped, for The House of Breath (1949).
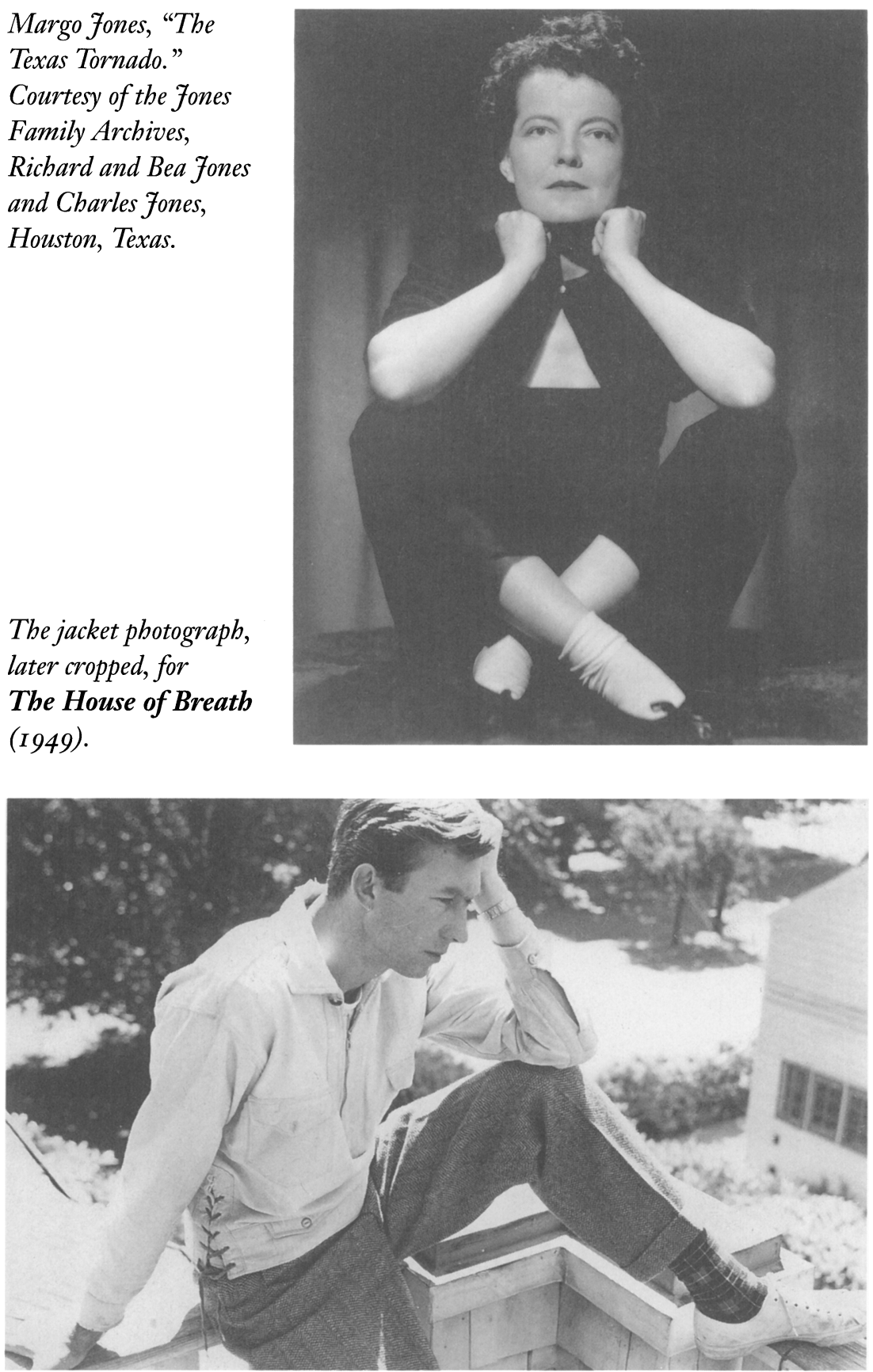
Foe Glasco in Alphonso Ossario's Paris studio, I950. Courtesy of Contemporary Arts Museum, Houston, Texas.

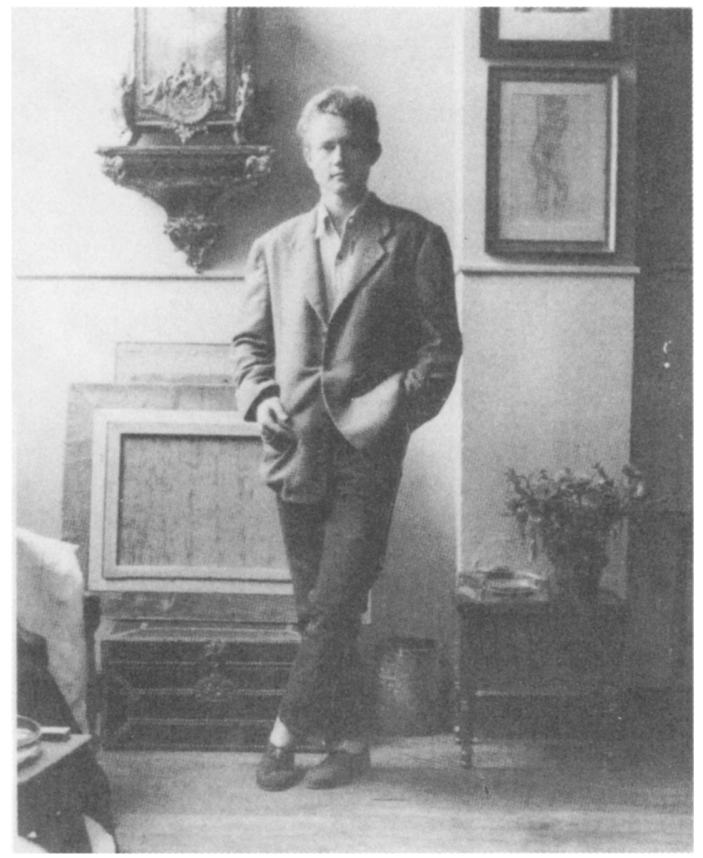

Goyen in a 1952 publicity shot. Photograph by Edward A. Bourdon. Courtesy of Random House, Inc.

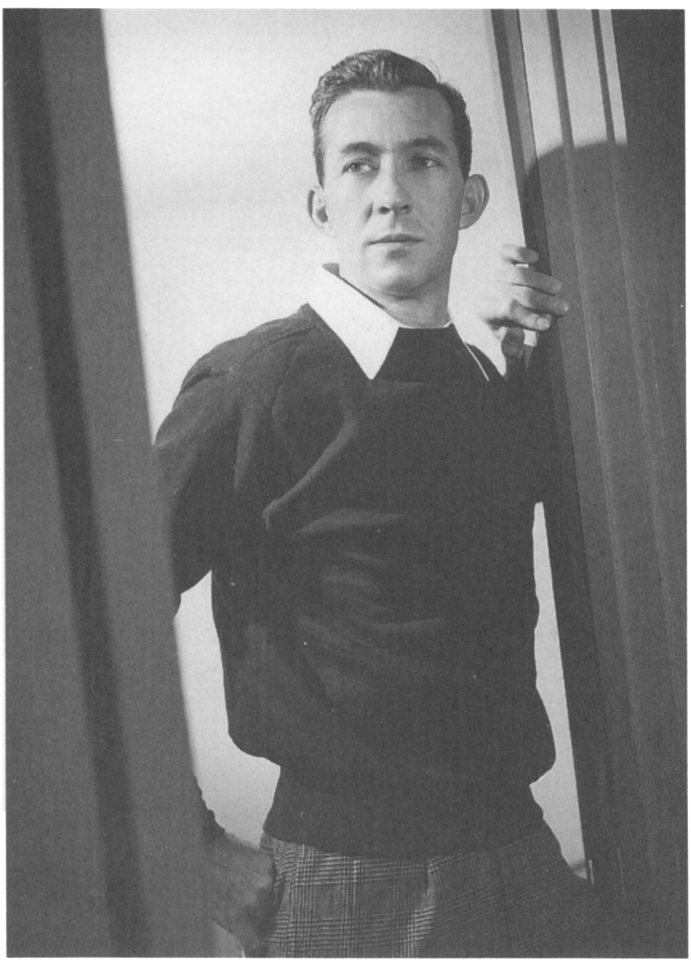




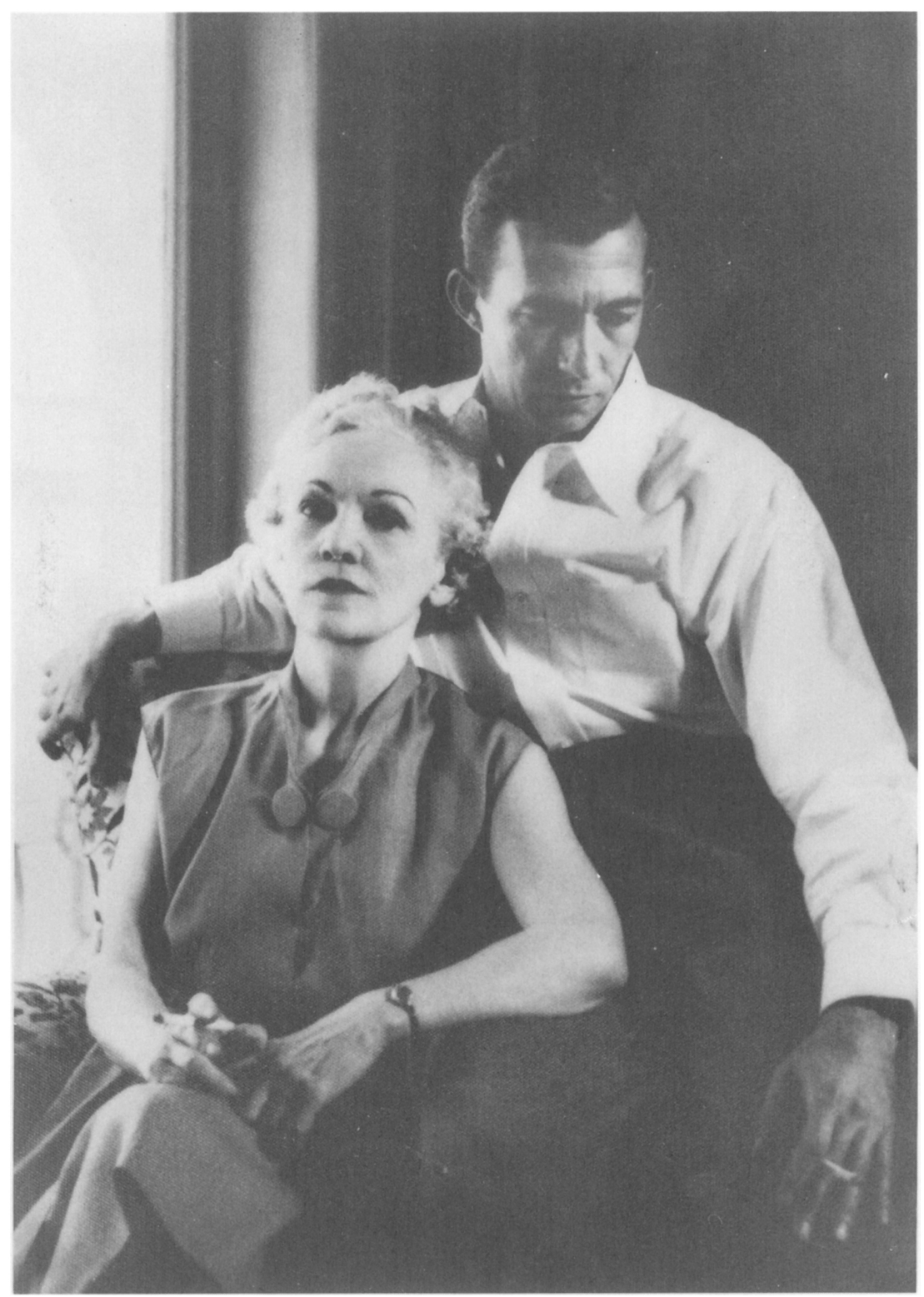

Katherine Anne Porter and Goyen in 1951. Photograph by Artbur Long. Courtesy of Special Collections, University of Maryland Libraries. 


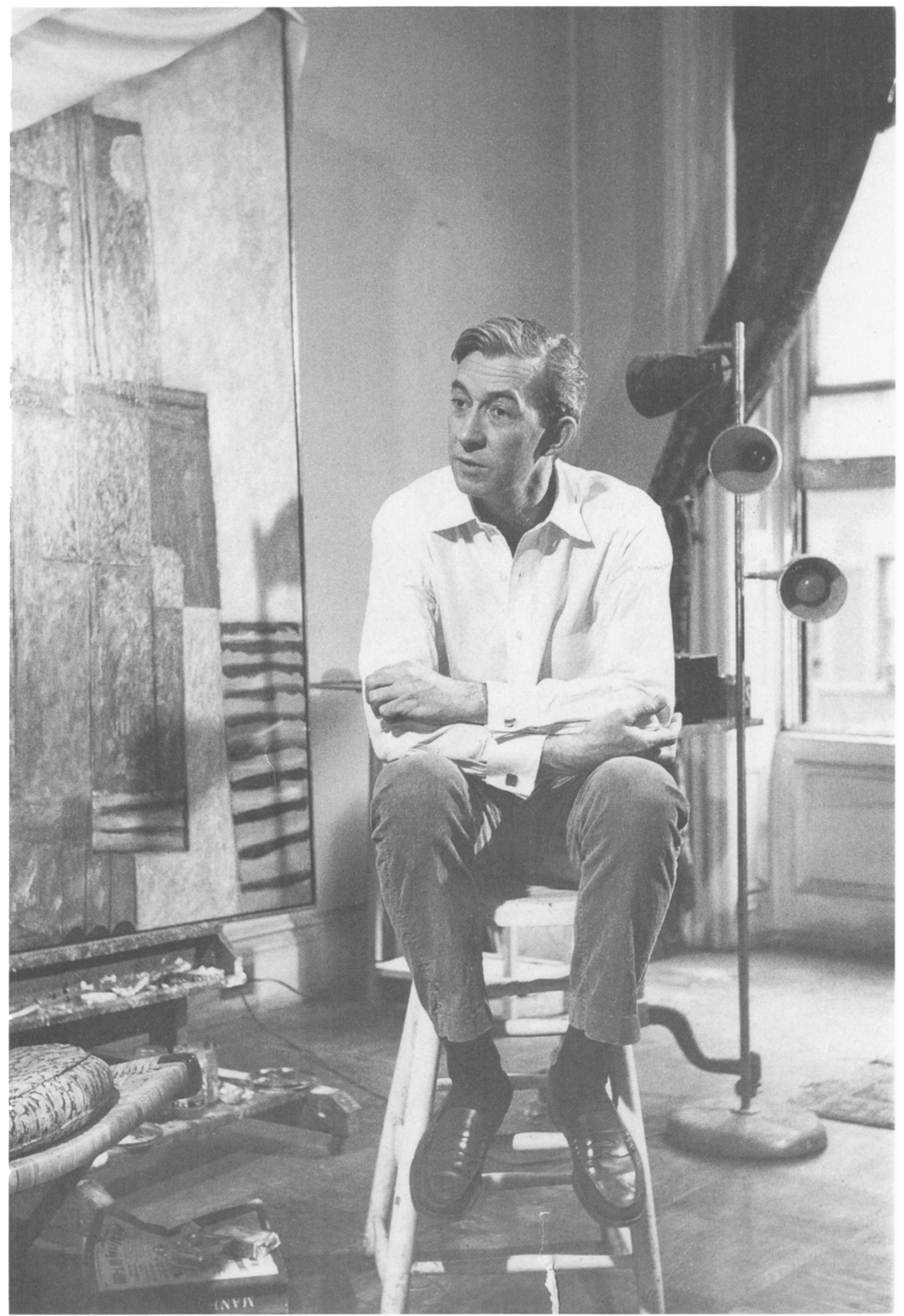

Goyen in Manhattan studio, I952. Opposite page, top left: Goyen's German translator, Ernst Robert Curtius, Fune I952. Top right: Goyen's French translator, Maurice Edgar Coindreau. Bottom: Doris Roberts and Goyen at the time of their marriage in November 1963. Photograph by Ben McCall. Courtesy of Doris Roberts. 

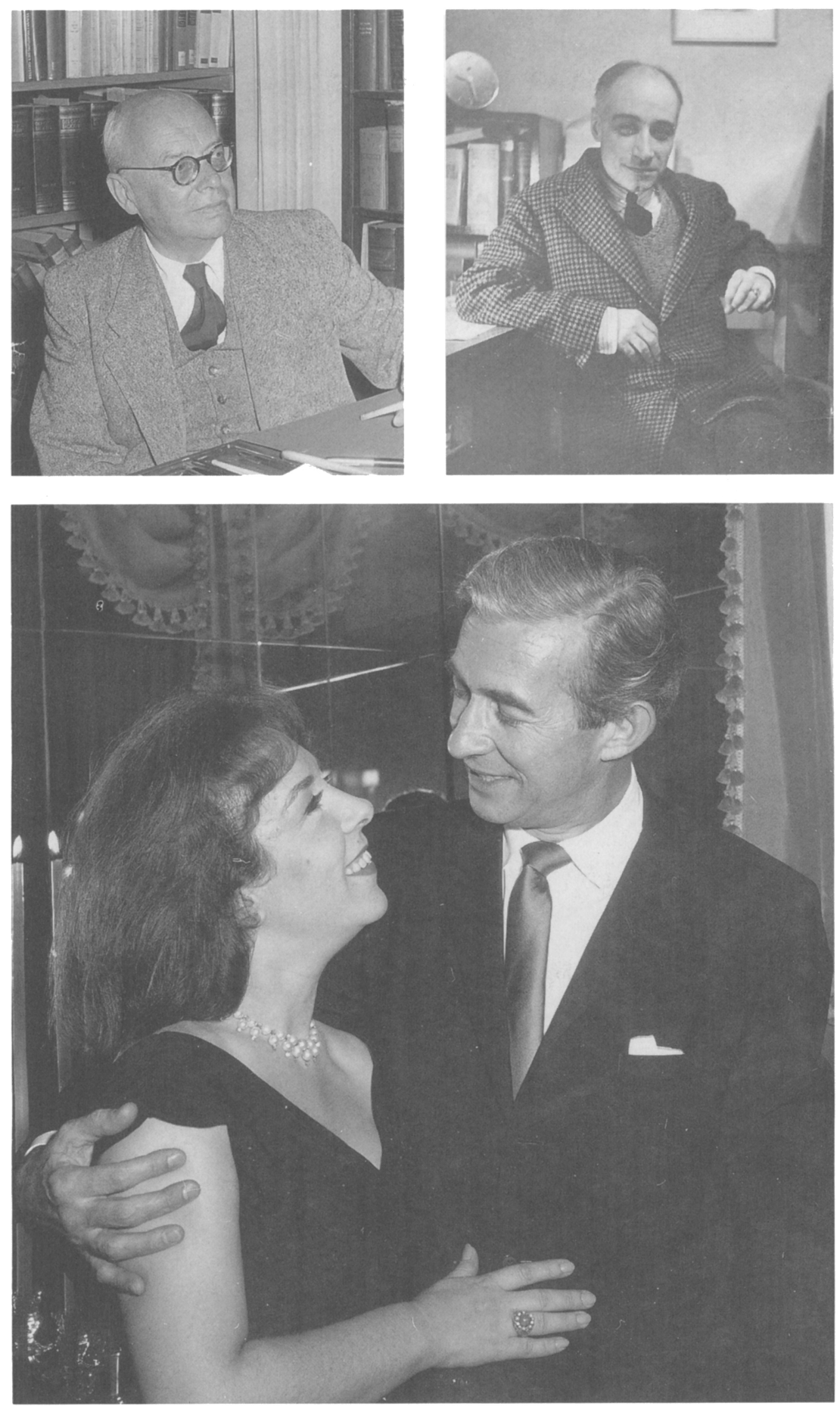


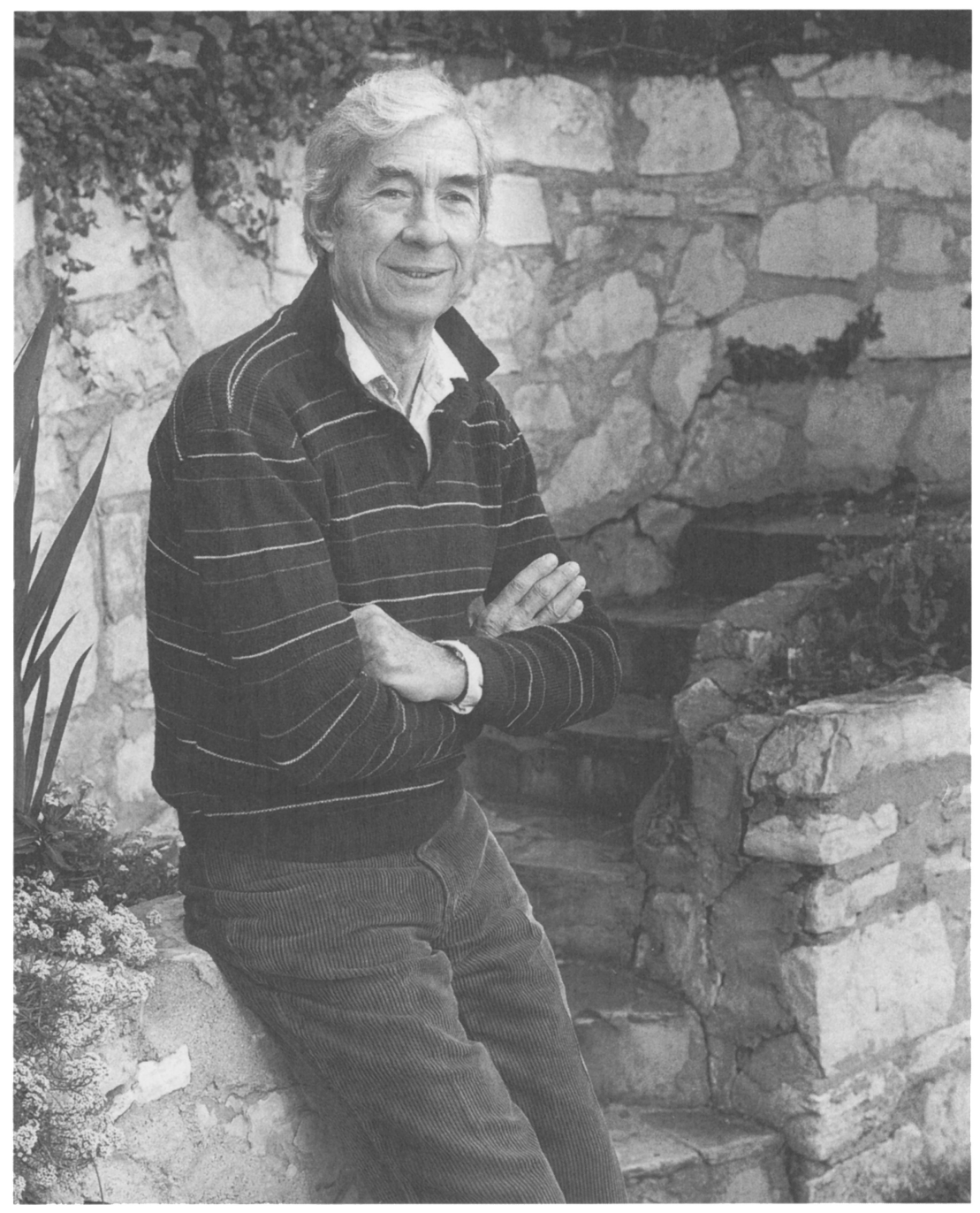

Goyen in bis Los Angeles backyard, 1983. Photograph by 7. Gary Dontzig. Courtesy of Doris Roberts. 
William Goyen

Selected

Letters

from a

Writer's

Life 
THIS PAGE INTENTIONALLY LEFT BLANK 